\title{
Influence of environmental factors and sheep grazing on an Andean grassland
}

\author{
PETER B. ADLER AND JUAN MANUEL MORALES
}

Authors are graduate research assistant, Dept. of Rangeland Ecosystem Science, Colorado State University, Fort Collins, Colo 80521; and Fulbright fellow, Dept. of Zoology, North Carolina State University, Raleigh, N.C. 27695. At the time of the research, the second author was supported by CONICET at the Laboratorio de Investigaciones Ecológicas de las Yungas, Universidad de Tucuman, Horco Molle, Tucuman, Argentina.

\begin{abstract}
Chronic overgrazing in the central Andes alters vegetation and may cause erosion and loss of productivity, but quantitative studies are lacking. We measured the relative influence of environmental factors and sheep grazing on local plant species composition, diversity, and soil organic matter in a remote site in northwestern Argentina. Using redundancy analysis, we found that environmental variables explained $22 \%$ of variation in species composition between sites, while grazing-related variables explained $24 \%$ of variation. The complete model, incorporating all significant variables, explained $33 \%$ of variation. Aspect, season of grazing (wet vs. dry) combined with total vegetative cover, and soil type formed the basis for the first 3 ordination axes. Unpalatable or toxic species and very low-growing species were significantly more abundant on heavily grazed sites compared to relatively protected sites. Stocking rate in wet season pastures was negatively correlated with total cover, forage volume, soil organic matter, and species richness. Season of grazing had a more dramatic effect on total cover, forage volume, species diversity and soil organic matter, which were all significantly lower in wet season pastures compared to dry season pastures. Season of grazing and aspect interacted strongly: wet season pastures on north aspects appear more susceptible to degradation and changes in species composition than south-facing sites. Our results suggest that protecting pastures during the summer rainy season may be an important complement to traditional management efforts to reduce stocking rates.
\end{abstract}

Key Words: Andes, grazing effects, plant ecology, ordination, pastoralism.

This research was supported by a 1996-1997 Fulbright fellowship and 1998 N.S.F. Pre-doctoral fellowship to P.B.A. Authors wish to thank Dr. C. Reboratti of the Universidad de Buenos Aires, Ing. R. Neuman and Dr. A.R. Bianchi of INTA, Ing. L. Novara of the Universidad Nacional de Salta, and especially the people of the village of Nazareno for invaluable help and friendship. Special thanks to Ing. A. Sulekik for determining the grass species. Dr. H.R. Grau, Dr. W.K. Lauenroth, Dr. J. Powell, and 3 anonymous reviewers provided helpful comments on early drafts of the manuscript.

Manuscript accepted 11 Nov. 1998.

\section{Resumen}

El sobrepastoreo crónico en los Andes centrales altera la vegetación y puede llegara causar erosión y pérdida de productividad. En el noroeste de Argentina estudiamos la influencia relativa de factores ambientales y pastore por ovejas en la composición y diversidad de plantas, y contenido de materia orgánica en el suelo. Usando una combinación de ordenamientos directos e indirectos, encontramos que las variables ambientales explicaron $22 \%$ de la variación en la composición de especies entre sitios,mientras que $24 \%$ 'fue explicado por variables relacionadas al pastoreo. Considerando todas las variables significativas se explicó 33\% de la variacion Los 3 primeros ejes del ordenamiento estuvieron formados por exposición temporada de pastoreo (húmeda vs seca) junto con cobertura vegetal, y tipo de suelo. Las plantas tóxicas o no palatables, $y$ plantas muy bajas, fueron significativamente más abundantes en sitios con mucha presión de pastoreo. En sitios pastoreados durante la época húmeda, la presión de pastoreo estuvo negativamente correlacionada con la cobertura vegetal total, el volumen de forraje, materia orgánica del suelo y riqueza de especies. La temporada de pastoreo tuvo un efecto más fuerte; los sitios pastoreados durante la temporada húmeda tuvieron menor cobertura total, volumen de forraje, diversidad de especies y materia orgánica en el suelo que los sitios pastoreados en la época seca. La temporada de pastoreo y la exposición interactuaron fuertemente; los sitios pastoreados durante la temporada húmeda en pendientes con exposición Norte parecen más suceptibles a degradarse y a cambiar en composición de especies que los sitios con exposición Sur. Nuestros resultados sugieren que proteger las pasturas durante el verano lluvioso puede ser un complemento importante de los esfuerzos por reducir la carga animal.

Overstocking of Andean rangelands is thought to cause increased erosion (Harden 1993, Molinillo 1993) and loss of productivity (Eckholm 1975, Parker and Alzérreca 1978). Selective grazing, especially by sheep, is usually invoked as the mechanism driving changes in species composition through the replacement of palatable species by coarse bunchgrasses (Ellenburg 1979, Ruthsatz and Fisel 1984). These problems affect virtually all Central Andean highlands 
(Ellenburg 1979, Fjeldsa and Kessler 1996). However, rigorous quantitative studies of the effects of grazing on vegetation and soils are lacking; for example, a review of well over 200 worldwide studies on the effects of grazing on vegetation and soils did not include a single study from the Andes (Milchunas and Lauenroth 1993).

Traditional range management relies heavily on adjustments of the stocking rate to manipulate vegetation condition. Yet the existence of non-reversible changes caused by intense grazing (Biswell 1956, Archer 1989) demonstrates problems with this approach. Current work on non-equilibrium systems suggests that stocking rate may not be the most important determinant of vegetation condition (Ellis and Swift 1988, Westoby et al. 1989). In fact, Turner (1993) found overstocking to be a very poor predictor of degradation potential in an African pastoral system. Especially in arid and semi-arid climates subject to high interannual variation in rainfall, abiotic and stochastic processes may influence ecosystem processes (Biondini and Manske 1996) and vegetation (Wiens 1984, West 1988) far more than biotic interactions such as herbivory.

In light of these findings, management practices should consider the impact of grazing on vegetation relative to other sources of variation. McIntyre and Lavorel (1994) provided a model for studying how an exogenous disturbance overlays patterns of vegetation related to the physiographic environment. Working in a semi-arid Australian rangeland, they used canonical correspondence analysis to quantify the amount of variation in species composition explained by environmental versus disturbance variables. They also identified significant associations between individual plant species and various environmental and grazingrelated factors.

McIntyre and Lavorel's (1994) approach allows us to describe the vegetation of a poorly studied grassland community in the Andes of northwestern Argentina while simultaneously quantifying the local impact of intense sheep grazing. Specifically, we aim to 1) determine the relative influence of grazing and environmental variables on plant species composition, and 2) show the effect of grazing on individual plant species and on stand-level variables such as total cover, species richness, and soil organic matter.

\section{Methods}

\section{Study Area}

The Cordillera Oriental of northwestern Argentina is remote and undeveloped, an extremely rugged area (Fig. 1) where subsistence remains the most important economic activity (Reboratti 1996). Few studies have examined the transitional grasslands between cloud forests and high desert, the focus of human activity in the region. Viera and Menéndez (1981) mapped geomorphic features and vegetation from aerial photos and Mendiola (1996) described plant species composition.

The study area surrounds the village of Nazareno in Salta province $\left(22^{\circ} 30^{\prime} \mathrm{S}\right.$, $\left.65^{\circ} 70^{\prime} \mathrm{W}\right)$ located at an elevation of $3,000 \mathrm{~m}$. (Fig. 2). The site is influenced

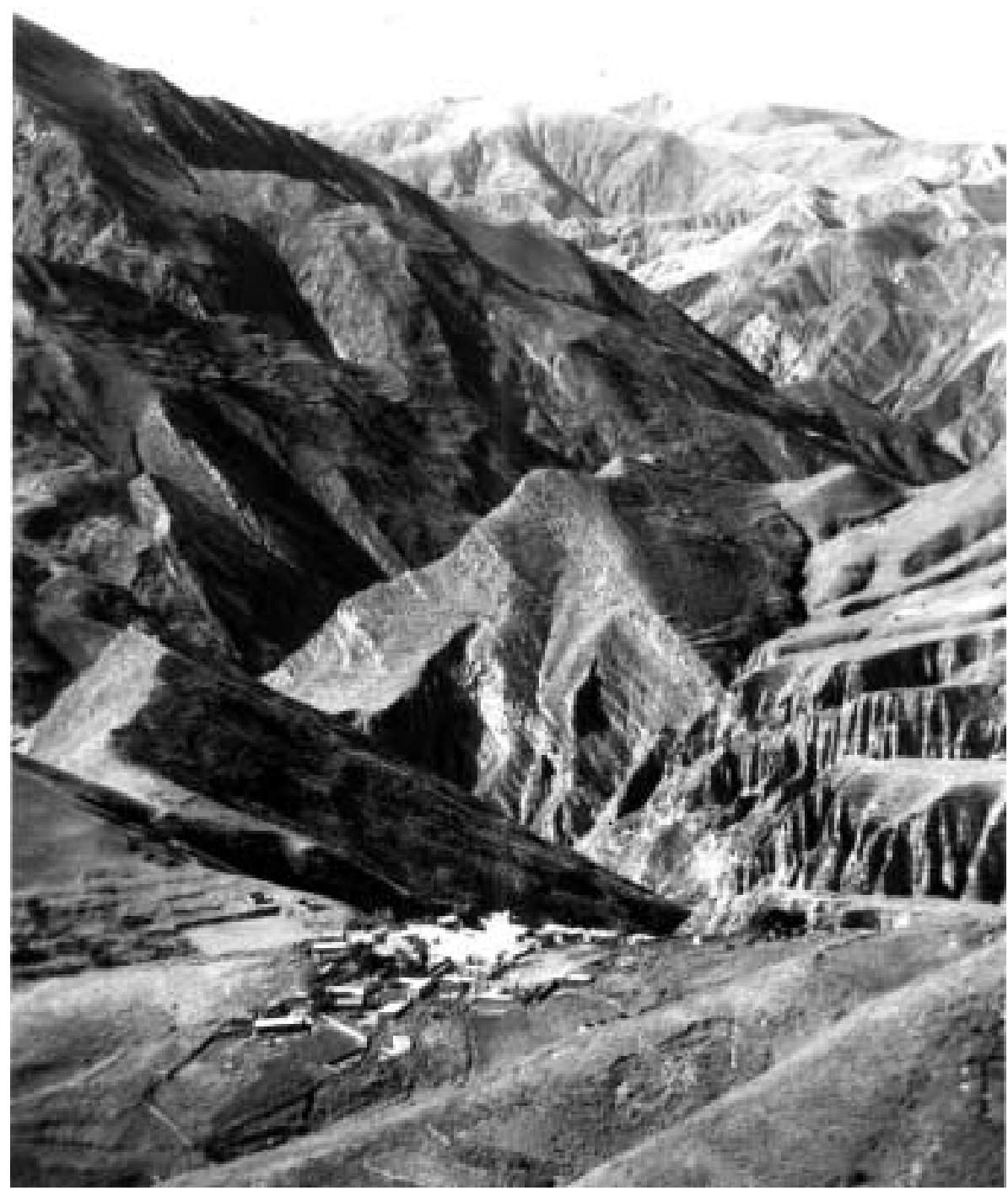

Fig. 1. The valley of the Río Nazareno and the village of Cuesta Azul, at the southern end of the study area. 


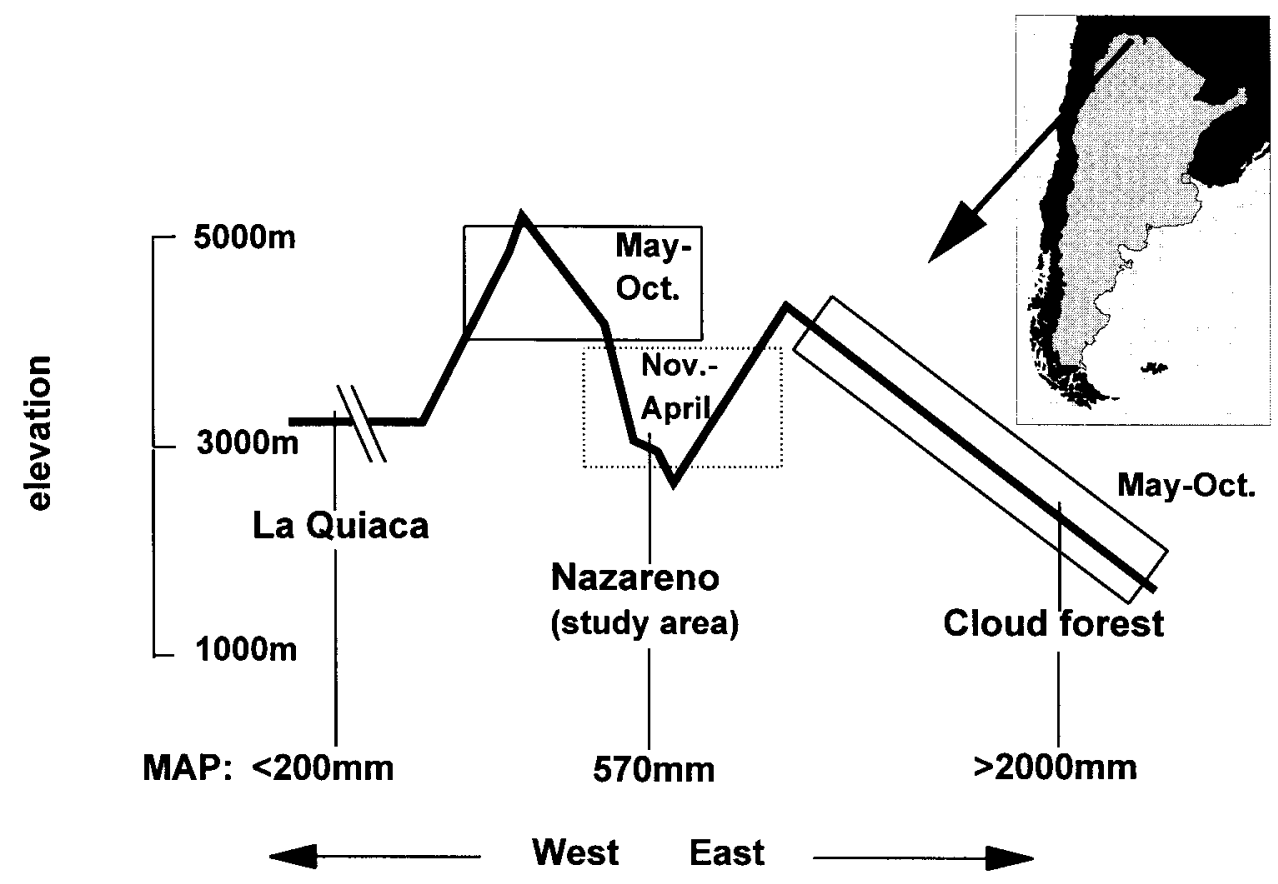

Fig. 2. Location of study site in northern Salta province, Argentina, and schematic elevation profile showing annual precipitation and pastoral movements.

by strong elevation and precipitation gradients. From October through April, the austral summer, air traveling westward from the Atlantic rises up the east slope of the Andes, drops most of its moisture over the rain and cloud forests, then becomes progressively drier. Mean annual rainfall declines from $2,000 \mathrm{~mm}$ at $1,000 \mathrm{~m}$ elevation at the eastern edge of the Andes to less than $200 \mathrm{~mm}$ in La Quiaca, on the Puna, or Altiplano (Bianchi 1981). Nazareno, in between these 2 extremes, receives $574 \mathrm{~mm} / \mathrm{yr}^{-1}$ (pers. comm. EVARSA, a regional utility). Seasonality is extreme, with virtually all rainfall occurring between October and April. Inter-annual variation in rainfall is low; in the 7 years of data available for Nazareno, annual rainfall ranged from $490 \mathrm{~mm}$ to $640 \mathrm{~mm}$. Total precipitation during the study year was $597 \mathrm{~mm}$, slightly above the mean. Frosts are frequent from April to October (Bianchi 1981). Steep slopes and weak sedimentary rock make the area highly susceptible to erosion and mass movement (Viera and Menendez 1981). Soils are shallow, rocky lithosoles with little organic material (Nadir 1990). The texture is sandy-loam with a high percentage of gravel, although within the study area deep pockets of clay-loam are frequent as well. Vegetation is characterized by large perennial bunch grasses (especially Stipa and Festuca species), interspersed with scattered shrubs such as Baccharis, Adesmia, and Senna species.

\section{Pastoral System and Stocking Rates}

Most pastoralists near Nazareno follow a transhumant strategy in response to seasonal fluctuations of forage availability. Women or children move the family's herd of typically 50 to 150 sheep and goats to the high mountains following the harvest, then to the montane forests during the winter dry season, before returning to their villages for the summer wet season (Fig. 2). The variety of movements makes generalization difficult, and some families graze their sheep and goats year-round near their permanent home in the valley. This study focuses solely on the valley pastures surrounding Nazareno and its neighboring villages.

Almost all rangelands in the valley are communal in a legal sense, but each family retains rights through long-standing tradition to a particular sector usually surrounding their home. These zones of roughly 50 ha (with great variation) may overlap, but their boundaries are recognized and respected. Scattered within this heavily grazed matrix are small areas of natural vegetation contained within fences built to protect agri- cultural fields from livestock, or to maintain dry season forage reserves. Not grazed until after the harvest in May, these protected sites are exceptions to the widespread wet season grazing in the valley and were sampled as "dry season" sites. They range in size from 1 ha to approximately 20 ha and are composed of the same vegetation as the adjacent "wet season" pastures.

Sheep are the dominant form of livestock, though horses, burros, and cattle are common. Our estimations of stocking rates include only sheep grazing for the following reasons: first, because horses graze very close to the houses, and cattle generally high in the mountains or near the cloud forests, sheep are the principal grazers on most of the valley rangelands. Second, since sheep are taken to pasture every day by a shepherd and are confined to the family's sector, their movements can be easily mapped, in contrast to the free-ranging cattle. Based on conversations with the pastoralists, most families have maintained a fairly constant herd size for at least a generation. Our study therefore concerns the effects of historical, rather than single-year, sheep grazing.

To calculate stocking rates during the wet season, we collaborated with workers from a livestock production program initiated by the Spanish missionary 
organization OCLADE (Obras Claretianas para el Desarollo). These extension workers showed us each pastoralist's grazing sector and supplied census information on the size and composition of their herd, and the length of time the animals remain in the sector each year. This information was supplemented by informal interviews with the pastoralists. Using aerial photos to estimate the surface area of each sector, we calculated the number of sheep and goat days per hectare. Before further statistical analysis, we divided the stocking rate (sheep and goat-days ha ${ }^{-1}$ ) by a logarithm of the distance between the corral and the sampling site, assuming grazing intensity within each sector decreases with distance from the corral.

We were unable to calculate stocking rate for the dry season sites. Grazing on these small pastures is generally concentrated in an intense pulse during the 3 or 4 weeks following harvest and all species-horses, burros and cattle, in addition to sheep and goats-are present. Therefore, our analysis of the effect of stocking rate is limited to the subset of sites grazed during the wet season, while that of the effect of season of grazing includes all sites.

\section{Vegetation Sampling}

We sampled in upland natural grasslands extending $10 \mathrm{~km}$ north and $8 \mathrm{~km}$ south from the village of Nazareno, on the west side of the Río Nazareno. We attempted to minimize site-to-site variation in altitude, which would otherwise be the dominant influence on vegetation in this high-relief landscape (sampled sites ranged from 2,914 to 3,383 meters above sea level). Sites fall into 2 broad land-use categories: pastures grazed during the summer wet season and pastures grazed only during the winter dry season. Between January and March of 1997, fifty-seven plant surveys were completed along a trail contouring at a relatively even elevation on small eastwest trending ridges. In general, we sampled 1 site on both the north and the south aspect of each ridge, locating the site subjectively in a patch of the most representative vegetation. Forty sites were located in summer wet season pastures; 17 sites were located in winter dry season pastures. At the time of sampling, dry season pastures had not yet been grazed.
We measured species composition and cover using 2 paired 10-meter line intercept transects, recording the cover of all plant species, rock, and bare ground. The parallel transects, 10 meters apart, ran with the slope, to cross the ubiquitous stock trails at a $90^{\circ}$ degree angle. Botanical nomenclature follows Cabrera (1977-1983). We also estimated the average height of all plant species on each transect. Environmental variables including aspect (2 classes: north and south), slope, and elevation were measured. A sample of the first $10 \mathrm{~cm}$ of soil was collected from between the transects. Soil samples were analyzed for organic carbon and total organic material at the Instituto Nacional de Tecnología, Agropecuaria (INTA ) in Cerrillos, Salta, using a wet combustion method (Walkley and Black 1934). Before samples were prepared for analysis, technicians classed soil texture qualitatively.

Information on palatability of plant species was gathered from pastoralists and Fernandez et al. (1992). "High" palatability indicates species always consumed. "Medium"describes plants which may be palatable at only 1 time of the year (usually at the start of the growing season) or eaten only in the absence of more palatable alternatives. "Poor" palatability is reserved for species that are minimally consumed and toxic species. The large number of species for which we had no information were excluded from this analysis. Using plant height and cover we calculated biovolume, a proxy for biomass (dePietri 1992). The biovolume of palatable species was summed to yield "forage volume."

\section{Data Analysis}

Ordination techniques can be used to characterize community level responses to environmental and disturbance variables, as well as to identify species sensitive to particular factors. Ordination axes can be constrained as linear combinations of a priori defined or measured variables associated with species records. As in general linear models, these variables can be combined in a stepwise manner (ter Braak and Prentice 1988). To further test independence, ordinations can be conducted after the effects of a variable or set of variables has been removed (partial analysis, Borcard et al. 1992, Okland and Eilertsen 1994).
To decide whether to use eigenvector techniques based on unimodal or linear species responses, we made scatter plots of species abundance and some of the environmental gradients, and considered the "length of gradient" measured in standard deviation units obtained by detrended correspondence analysis (DCA). After judging by eye that most species showed nearly linear responses within the observed range, and having obtained relatively short gradients in DCA ordinations (always less than 3 SD), we decided to use redundancy analysis (RDA) as our constrained ordination technique.

In the CANOCO version of RDA the fraction of the total variation in the species matrix “explained' by a variable or set of variables can be directly read from the sums of constrained eigenvalues (Jongman et al. 1987, Borcard et al 1992). We used 99 unrestricted permutations of the constraining variable (Monte Carlo test in CANOCO, ter Braak 1990a) to assess the statistical significance of each variable. The terms "explanation" and "variation explained" are used here in a statistical sense rather than implying cause and effect. As infrequent species of random occurrence can give rise to spurious effects (Jongman et al. 1987), we excluded from the analysis species with frequency lower than $5 \%$ (66 taxa excluded, 115 included). All cover data were log-transformed to prevent high-cover species from disproportionately influencing the analysis.

To study the effects of environment and grazing we followed McIntyre and Lavorel (1994). First, we looked for significant structuring of the species data in relation to environmental variables and their interactions (aspect: north or south; soil type: clay-loam or sandy-loam; slope; elevation). Second, we quantified the effects of the grazing-related factors (stocking rate in wet season pastures; season of grazing: wet or dry; total vegetative cover; soil organic matter; date of sampling). "Grazing-related factors" are either management practices, variables directly affected by grazing, or, in the case of date of sampling, a rapidly changing variable in comparison to the "fixed" environmental factors. Third, we put both environmental and grazing factors into 1 complete model and used partial ordination to study the effects of grazing regime once environmental effects had been taken into account. In 
each model, variables were included in forward stepwise selection after satisfying a Monte Carlo test.

Since Redundancy Analysis (RDA) is a form of multivariate multiple regression the results of the analysis include regression coefficients and associated tvalues. An objective way to identify individual species significantly correlated with explanatory variables in RDA is by examining the t-value biplots, which are 2-dimensional graphs showing the $\mathrm{t}$ values of the regression coefficients for a given species on the explanatory variables (ter Braak 1990b). We used this technique to classify species according to their association with environmental and grazing related factors. All analysis were performed using the program CANOCO version 3.12 (ter Braak 1987, 1990a).

To evaluate the effect of stocking rate (wet season pastures only) on stand-level variables, we performed a rank transformation of stocking rate, then used Spearman rank order correlations. To test differences in these variables caused by season of grazing and aspect, one-way ANOVA was used. We tested the relationship between

Table 1. Test of significance of explanatory variables for species composition. "Variation Explained" = eigenvalue of constrained axis divided by the sum of all eigenvalues. Variables included in the complete model are shown in boldface, with percent variation explained once incorporated in the model in brackets. $\mathrm{P}=$ significance probability of the constrained axis in a Monte Carlo permutation test $\left(\mathrm{H}_{0}=\right.$ influence of variable not significantly different from random).

\begin{tabular}{lcc}
\hline \hline & $\begin{array}{c}\text { Variation } \\
\text { Vxplained }\end{array}$ & $\mathrm{P}$ \\
\hline a. Environmental variables & $(\%)$ & \\
Elevation & 2.0 & 0.66 \\
Aspect & $\mathbf{1 0 . 2}(8.0)$ & 0.01 \\
Soil & $\mathbf{6 . 4}(6.1)$ & 0.01 \\
Slope & 4.3 & 0.01 \\
Elevation*Aspect & 11.2 & 0.10 \\
Elevation*Soil & 8.5 & 0.07 \\
Elevation*Slope & 2.5 & 0.04 \\
Aspect*Soil & 18.8 & 0.01 \\
Aspect*Slope & 13.3 & 0.01 \\
Soil*Slope & 10.7 & 0.01 \\
Aspect*Soil+Slope & 21.6 & 0.01 \\
b. Grazing-related variables & & \\
Date (day of sampling) & $\mathbf{4 . 6}(2.5)$ & 0.02 \\
Season (of grazing) & $\mathbf{9 . 4}(4.5)$ & 0.01 \\
Stocking rate (sheep-days/Ha) & 7.8 & 0.01 \\
Total cover & $\mathbf{1 0 . 2}(4.7)$ & 0.01 \\
Soil organic matter & 7.1 & 0.01 \\
Cover+Season+S.O.M.+Date & 23.6 & 0.01 \\
\hline
\end{tabular}

Table 2. Eigenvalues of the first 4 axes in the complete model RDA and correlation coefficients with the environmental and grazing variables. Total=sum of all eigenvalues. Boldface indicates the factor most strongly correlated with each axis.

\begin{tabular}{lrrrrr}
\hline \hline & Axis 1 & Axis 2 & Axis 3 & Axix 4 & Total \\
\hline Eigenvalue & 0.1142 & 0.1032 & 0.0571 & 0.0388 & 0.332 \\
Aspect & $\mathbf{- 0 . 8 2 9 2}$ & 0.3649 & 0.3792 & 0.1628 & \\
Soil Type & -0.3566 & -0.0117 & $\mathbf{- 0 . 9 2 4 2}$ & 0.1019 & \\
Date (of sampling) & 0.0825 & 0.5490 & 0.0488 & -0.2210 & \\
Season of Grazing & -0.2312 & $\mathbf{- 0 . 9 0 0 6}$ & 0.0564 & 0.2454 & \\
Total Cover & 0.6347 & 0.7126 & -0.0053 & 0.2856 & \\
\hline
\end{tabular}

grazing response and species palatability and stature with a non-parametric ANOVA (Kruskal-Wallis $\mathrm{H}$ ) using species' scores from the ordination. For these tests we used SPSS 8.0 for Windows and rejected the null hypothesis at $P<05$.

\section{Results and Discussion}

\section{Effects of Environmental Variables on Species Composition}

Each environmental factor except altitude, which we limited to a range of less than $400 \mathrm{~m}$, explained a small but significant proportion of variation in species performance (Table 1a). Aspect accounted for the highest inter-site variability in species composition (see Appendix for species list). A total of 19 species were recorded exclusively in sites facing south but only 4 species were found exclusively in sites facing north. Soil type was ranked second in amount of variation explained. Eight species were found exclusively at sandy-loam sites and 4 species were recorded only at clay-loam sites.

The combination of aspect and soil type explained $19 \%$ of total variation. In this ordination, the first axis separates north and south aspects, while the second axis separates sandy-loam from clay-loam soils. After incorporating the combined effects of aspect and soil type, the only environmental variable that could significantly increase the amount of variation explained was slope. The "best fitting" model based on environmental variables accounted for $22 \%$ of total variation (Table 1a).

\section{Effects of Grazing-related Factors}

Differences in total vegetation cover and season of grazing were the most important factors accounting for variation in species composition. Stocking rate and season of grazing had similar explanatory power when taken independently (Table 1b). However, once the effects of season of grazing were incorporated into the model, stocking rate was no longer significant. The model incorporating all significant variables (cover, season, organic matter, and date of sampling) explained $24 \%$ of the total inter-site variability in species composition. This value is slightly higher than the best fitting environmental model.

In this ordination of grazing-related factors, the first axis related to the contrast between total cover and season. High cover sites correlate with sites protected during the wet season, low cover sites correlate with sites grazed during the wet season. The second axis was associated with organic matter content, and the fourth axis was dominated by date of sampling. The first 2 axes accounted for $79 \%$ of the total $(24 \%)$ variation explained by the set of grazing related variables.

The importance of grazing relative to environmental factors attests to the intensity of land-use in this landscape. In fact, we may have underestimated the influence of land-use due to a lack of information on 2 potentially important sources of variation, historical grazing patterns and the traditional use of fire to stimulate early season growth.

\section{Combined Effects of Environmental and Grazing Factors}

The complete model, which incorporates in a stepwise manner both environmental and grazing related variables, accounted for $33 \%$ of the total variation in the species matrix (Table 2), similar to comparable studies (Lavorel et al. 1991, McIntyre and Lavorel 1994). In this ordination the first axis is related to aspect, the second axis captures variation related to season of grazing and 
Table 3. Individual species affected significantly (t-value biplot score $|<| 1 \mid)$ by season of grazing in the complete model RDA.

\begin{tabular}{|c|c|c|c|c|}
\hline Family & pecies & $\begin{array}{l}\text { T-value } \\
\text { Biplot }\end{array}$ & $\begin{array}{l}\text { Variation } \\
\text { Explained }\end{array}$ & Palatability \\
\hline \multicolumn{2}{|c|}{ a. Wet Season Pasture Species } & \multicolumn{3}{|c|}{$\%$} \\
\hline Apiaceae & Bowlesia cf. pulchella Wedd & -0.476 & 23.09 & unknown \\
\hline Asteraceae & Baccharis multiflosculosa Heering & -0.484 & 17.07 & poor \\
\hline Poaceae & Stipa ichu (R. et P.) Kunth & -0.625 & 14.28 & poor \\
\hline Poaceae & Nasella pampagrandensis (Spreg.) Barkworth & -0.695 & 10.21 & poor \\
\hline Oxalidaceae & Oxalis argentina Knuth & -0.702 & 9.78 & medium \\
\hline Asteracea & Achyrocline ramosissima $\mathrm{Sch}$. Bip. & -0.740 & 10.04 & unknown \\
\hline Pteridophyta spp. & & -0.885 & 7.72 & poor \\
\hline Convolvulaceae & Dichondra sericea v. microcalyx $\mathrm{Sw}$. & -0.887 & 6.76 & medium \\
\hline Poaceae & Sporobolus indicus (L.) R. Br. & -0.904 & 8.21 & poor \\
\hline Poaceae & Bromus catharticus Vahl. & -0.907 & 5.26 & high \\
\hline Fabaceae & Senna alata (L.)Rox. & -0.909 & 7.94 & medium \\
\hline \multicolumn{5}{|c|}{ b. Protected Site Species } \\
\hline Asteraceae & Tagetes minuta Linn. & 0.462 & 18.65 & medium \\
\hline Poaceae & Diplachne dubia (HBK) Scribn. & 0.598 & 17.18 & high \\
\hline Asteraceae & Stevia minor Gris. & 0.624 & 11.84 & medium \\
\hline Poaceae & Lycurus phalaroides Kuntze & 0.628 & 15.55 & unknown \\
\hline Poaceae & Paspalum humboldtianum Flugge & 0.695 & 13.78 & high \\
\hline Oxalidaceae & Hypseocharis tridentata Griseb. & 0.730 & 10.39 & high \\
\hline Asteraceae & Gutierrezia mandonii Sch. Bip. & 0.786 & 9.19 & medium \\
\hline Asteraceae & Hypochoeris elata Wedd. & 0.854 & 5.37 & medium \\
\hline Poaceae & Botriochloa sp. & 0.897 & 7.71 & medium \\
\hline Convolvulaceae & Ipomoea minuta f. minuta $\mathrm{R}$. Fries & 0.925 & 7.92 & poor \\
\hline Poaceae & Muhlenbergia rigida $(\mathrm{HBK})$ Trino & 0.944 & 5.07 & medium \\
\hline Poaceae & Deyeuxia tarmensis Pilg. & 0.977 & 4.54 & medium \\
\hline Poaceae & Festuca spp. & 0.984 & 4.76 & medium \\
\hline
\end{tabular}

total cover, while the third axis represents variation due to soil type. Except for covariation of total cover with both aspect and season, the primary 3 factors (aspect, season, and soil type) are largely orthogonal (Table 2).

Partial ordination of grazing related factors once the environmental factors were taken into account explained $16 \%$ of the species matrix. This implies that one-third ( $8 \%$ out of $24 \%$ ) of variation explained by grazing related factors was structured in the environmental matrix. Again, total cover and season were the most important variables.

\section{Effects on Individual Species}

T-value biplots indicated that species were significantly associated with grazing (Table 3) and environmental factors (see Appendix). Perennial grasses were particularly sensitive to wet versus dry season grazing. Stipa ichu (R. et P.) Kunth and Nasella pampagrandensis (Spreg.) Barkworth were indicators for sites grazed in the wet season, while Diplachne dubia (HBK) Scribn., Lycurus phalaroides Kuntze, Paspalum humboldtianum Flugge and Festuca spp. were characteristic of dry season pastures. If associations with total cover are plete ordination were significantly related to palatability (Table 4). The rank means for the medium and high palatability classes were similar, while the rank mean for the poor palatability class was much lower. Low-growing species were significantly more common on the heavily-grazed sites (Table 4). This effect was strongest when species less than $7 \mathrm{~cm}$ were compared to all taller species, and became insignificant when the limit of the short class was moved up to $15 \mathrm{~cm}$.

These results support the prevailing view in the Andes that changes in species composition due to grazing are driven by differential palatability. As previous research has indicated, Stipa $i c h u$, a typical coarse, unpalatable bunchgrass, is characteristic of heavilygrazed wet season pastures (Ellenburg 1979, Ruthsatz and Fisel 1984). Avoidance of highly unpalatable and toxic species appears to be more important than selection of highly palatable species, which were treated no differently than species of medium palatability.

The shift in composition to plants of lower stature on heavily-grazed sites suggests other possible mechanisms for differential response to grazing. Plants able to grow very low to the ground either avoid grazing, or have superior physiological responses to grazing compared to taller plants. Other studies in the Andes (Wilcox et al. 1987) and elsewhere (Noy -Meir et al. 1989, Belsky 1992) have identified the same pattern.

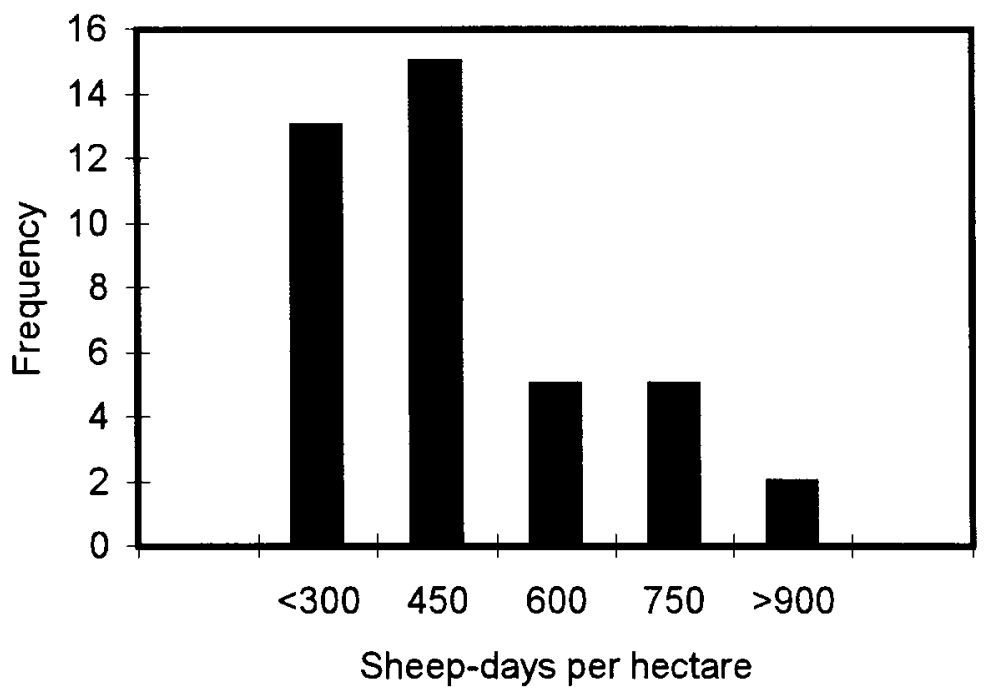

Fig. 3. Frequency distribution of stocking rates among the 40 wet season pastures. 
Table 4. Palatability and plant stature affect species' scores on the grazing related axis II of the complete ordination in non-parametric one-way ANOVA (Kruskal-Wallis H.) The effect of plant stature weakens as the limit between the short and tall class is increased.

\begin{tabular}{|c|c|c|c|c|}
\hline Variable and Class & $\mathrm{N}$ & Mean Rank & $\chi^{2}$ & $\mathrm{P}$ \\
\hline$\overline{\text { Palatability }}$ & & & $d f=2$ & \\
\hline Poor & 21 & 28.6 & 6.22 & .05 \\
\hline Medium & 38 & 40.9 & & \\
\hline High & 17 & 45.3 & & \\
\hline Plant stature & & & $d f=1$ & \\
\hline$<7 \mathrm{~cm}$ & 41 & 46.2 & 7.92 & .01 \\
\hline$>7 \mathrm{~cm}$ & 74 & 64.5 & & \\
\hline$<15 \mathrm{~cm}$ & 72 & 54.1 & 2.62 & .11 \\
\hline$>15 \mathrm{~cm}$ & 43 & 64.5 & & \\
\hline
\end{tabular}

Table 5. Spearman Rank Order Correlations among variables in wet season pasture site $(n=40)$.

\begin{tabular}{lccl}
\hline \hline Variables & Spearman R & $\mathrm{t}(\mathrm{n}-2)$ & $\mathrm{P}$ \\
\hline Stocking rate \& Total cover & -0.54 & -3.95 & .01 \\
Stocking rate \& Richness & -0.36 & -2.41 & .02 \\
Stocking rate \& Soil organic matter & -0.37 & -2.41 & .02 \\
Stocking rate \& Forage volume & -0.25 & -1.62 & .11 \\
Total cover \& Richness & 0.61 & 4.69 & .01 \\
Total cover \& Soil organic matter & 0.58 & 4.42 & .01 \\
Total cover \& Forage volume & 0.58 & 4.41 & .01 \\
\hline
\end{tabular}

Table 6. Differences between dry season $(n=17)$ and wet season $(n=40)$ pastures, using one-way ANOVA.

\begin{tabular}{lcccc}
\hline \hline Response Variable & $\begin{array}{l}\text { Mean Dry } \\
\text { Season Sites }\end{array}$ & $\begin{array}{c}\text { Mean Wet } \\
\text { Season Sites }\end{array}$ & F & P \\
\hline Total cover $(\%)$ & 133.0 & 67.0 & 51.42 & .01 \\
Forage $\left(\mathrm{cm}^{3}\right)$ & 1501.0 & 208.0 & 42.01 & .01 \\
H (Shannon-Weiner) & 3.9 & 3.5 & 7.46 & .01 \\
Soil organic matter $(\%)$ & 4.3 & 3.1 & 4.18 & .05 \\
Richness & 39.5 & 35.9 & 2.33 & .13 \\
\hline
\end{tabular}

Table 7. Mean percent cover and standard error of the mean (in parantheses) of important vegetation classes grouped by site aspect and season of grazing. Sample sizes are as follows: wet season $* \mathrm{~N}=20$, wet season $* \mathrm{~S}=20$, dry season $* \mathrm{~N}=9$, dry season $* S=8$.

\begin{tabular}{|c|c|c|c|}
\hline Aspect & Cover class & Wet season & Dry season \\
\hline & & & \\
\hline \multirow[t]{5}{*}{$\mathrm{N}$} & Grasses & $27.1(4.5)$ & $62.3(5.8)$ \\
\hline & Forbs & $16.4(2.6)$ & $49.9(6.7)$ \\
\hline & Shrubs & $8.7(2.4)$ & $15.6(4.8)$ \\
\hline & Ferns & $1.4(0.4)$ & $0.5(0.2)$ \\
\hline & Bare ground & $43.2(4.3)$ & $6.2(3.2)$ \\
\hline \multirow[t]{5}{*}{ S } & Grasses & $40.1(3.1)$ & $65.2(6.7)$ \\
\hline & Forbs & $20.2(2.1)$ & 39.7 (5.7) \\
\hline & Shrubs & $19.6(5.5)$ & $31.7(6.1)$ \\
\hline & Ferns & $1.5(0.4)$ & $0.2(0.1)$ \\
\hline & Bare ground & $18.4(2.7)$ & $3.0(1.2)$ \\
\hline
\end{tabular}

We could not confirm the significance of plant growth form (dePietri 1992) in determining species-level response, nor do we have data on species' physiological response. Fine-scale spatial relationships may be important as well: palatable species seemed to "hide" under larger shrubs.

\section{Stand-level Variables}

The mean stocking rate in wet season pastures was 362 sheep and goat-days ha $^{-1}$ each 6 month wet season, and ranged from 154 to 793 (Figure 3). The Spearman rank order correlations show significant inverse relationships between stocking rate in wet-season pastures and total cover, species richness, soil organic matter and forage volume (Table 5). Total cover is positively correlated with richness, soil organic matter, and forage volume (Table 5). Total cover may be as effective as stocking rate as an indicator of site condition.

Differences between wet season and dry season pastures are dramatic. Dry season pastures have much higher total cover, forage volume, plant species diversity, and soil organic matter (Table 6 ). Season of grazing did not significantly affect richness.

Aspect had a strong effect on standlevel variables, consistent with its influence on species composition. Forage volume, total cover, species richness and soil organic matter were much higher in wet season pastures on south aspects compared to north aspects (one-way ANOVA, $\mathrm{n}=40$, all F's $>8.00$, all $P<.01$ ). In dry season pastures, only soil organic matter was significantly higher on south aspects $(\mathrm{n}=16, \mathrm{~F}=6.06, P=.026)$. This apparent interaction between aspect and season of grazing (Table 7) led us to revisit our analysis of species composition. In the complete model Redundancy Analysis (RDA), an aspect*season of grazing interaction explained over $3 \%$ of variation in species composition even when aspect and season were included as covariables

Such a marked contrast between north and south slopes may not only be due to differences in solar radiation, but also to condensation from low clouds carried by the prevailing southerly winds in the summer wet season. These páramo-type grasslands have been termed "cloud pastures," analogous to cloud forests (Brown and Grau 1993), and unmeasured precipitation may be considerable, 
especially on southern aspects. South facing slopes, which probably receive and retain more water than north slopes, are apparently more resistant to degradation caused by wet season grazing.

\section{The Importance of Season of Grazing Compared to Stocking Rate}

Whether or not a site is grazed during the summer wet season, when vegetation is active, emerged as a critical determinant of both species composition and stand-level variables. Because we have no data on stocking rates during the dry season, it is possible that dry season grazing intensities are much lower than in the wet season, meaning that difference between wet and dry season pastures would be essentially a difference in stocking rate. Given the very small size of the dry season pastures and the intensity of land-use in the area, this seems unlikely. The shorter length of rotation could also explain the lesser impact of dry season grazing. However, previous work has shown that the effects of sheep grazing on vegetation do in fact depend on the season of grazing (Bork et al. 1998). The importance of protecting vegetation during the season of active growth and reproduction has been reported in other grazing systems as well (Bartolome 1993, Brown and Stuth 1993).

We can suggest a number of mechanisms for the severe impact of wet season grazing. Many species are only palatable during the early growing season and would be avoided in the dry season (Molinillo and Monasterio 1997), making it likely that less biomass is removed during dry season grazing. Trampling is more damaging when plants are active and soil wet and soft (Heady and Child 1994). Resulting soil compaction can dramatically alter hydrology, lowering infiltration and raising sediment production (Warren et al. 1986). Grazing during the reproductive season also can cause seed loss (Bertiller 1994). Finally, soil nutrient status, which may influence species composition (Tilman 1990), would be affected by both biomass removal and increased erosive action.

Stocking rate in the wet season was less effective than both season of grazing and total cover in explaining variation in species composition and differ- ences in stand-level variables. Clearly, the difficulties of measuring stocking rate in this complex, fenceless landscape hamper prediction. Without better estimations of stocking rate during both wet and dry seasons, we cannot exclude stocking rate as an important factor. However, it is possible that as Turner (1993) found in Africa, stocking rate may simply be a poor indicator of degradation potential.

\section{Management Implications}

Proposed management solutions in the Andes have generally focused on the need to reduce the total number of stock (LeBaron et al. 1979). Our findings suggest that protecting grasslands during the rainy season should at least complement if not significantly improve upon strategies based on reductions in stock. For example, we might suggest that the traditional annual rotation of herds through the landscape (from valley to cloud forest to high peaks) could be altered between years, allowing the valley pastures to rest in one rainy season, and the high peak pastures to rest in another. A second alternative to provide wet season protection would require further concentrating grazing pressure in some areas in order to rest others. If already degraded pastures prove stable under increased use, a reasonable possibility given the area's history of degradation, and if rested pastures do indeed recover, then the benefit of protecting one pasture might outweigh the cost of concentrating grazing on another pasture.

However, we present these alternatives pessimistically. The subsistence requirements of poor rural communities in the Central Andes, combined with environmental and cultural constraints, severely limit the potential for any management change (Browman 1987). Altering transhumant patterns, as we suggest in our first alternative, would force shepherds and their flocks to endure harsh, wet conditions among the peaks while missing Christmas and Carnaval in the valley villages, the most important social reunions of the year. Protecting areas within the wet season pastures, as in our second alternative, may be impossible without fences or the capital to construct them. On the other hand, the dramatic cultural and economic transformations affecting this region, initiated by greater integration with the national and global economy (Reboratti 1996), may generate novel perspectives and foster new approaches.

\section{Literature Cited}

Archer, S. 1989. Have southern Texas savannas been converted to woodlands in recent history? Amer. Natur. 134:545-561.

Bartolome, J.W. 1993. Applications of herbivore optimization theory to rangelands of the western United States. Ecol. Appl. $3: 27-29$.

Belsky, A.J. 1992. Effects of grazing, competition, disturbance, and fire on species composition and diversity in grassland communities. J. Veg. Sci. 3:187-200.

Bertiller, M.B. 1994. Modelos ecológicos alternativas de la dinámica de la vegetatción en ecosistemas de pastizales: Un caso de estudio en la Patagonia. Revista Argentina de Producción Animal 14:15-23.

Bianchi, A.R. 1981. Las Precipitaciones en el Noreoeste Argentino. Instituto Nacional de Tecnología Agropecuaria (INTA), Salta, Argentina.

Biondini, M.E. and L. Manske. 1996. Grazing frequency and ecosystem processes in a northern mixed prairie, U.S.A. Ecol. Appl.. 6:239-256.

Biswell, H.H. 1956. Ecology of Californian grasslands. J. of Range Manage. 9:19-24.

Borcard, D., P. Legendre, and P. Drapeau. 1992. Partialling out the spatial component of ecological variation. Ecol. 73:1045-1055.

Bork, E.W., N.E. West, and J.W. Walker. 1998. Cover components of long-term seasonal sheep grazing treatments on three tip sagebrush steppe. J. Range Manage. 51:293-300.

Browman, D.L. 1987. Agro-pastoral risk management in the Central Andes. Res. in Eco. Anthro. 8:171-200.

Brown, A.D. and H.R. Grau. 1993. La Naturaleza y el Hombre en las Selvas de Montaña Proyecto GTZ, Salta, Argentina.

Brown, J.R. and J.W. Stuth. 1993. How herbivory affects grazing tolerant and sensitive grasses in a central Texas grassland: Integrating plant response across hierarchical levels. Oikos 67:291-298.

Cabrera, A.L. 1977-1983. Flora de la Provincia de Jujuy, Repulica Argentina. Instituto Nacional de Tecnología Agropecuaria, Buenos Aires.

dePietri, D.E. 1992. The search for ecological indicators: is it possible to biomonitor forest system degradation caused by cattle ranching activities in Argentina? Vegetatio 101:109-121.

Eckholm, E.P. 1975. The deterioration of mountain environments. Sci. 189:764-770. 
Ellenburg, H. 1979. Man's influence on tropical mountain ecosystems in South America. J. of Ecol. 67:401-416.

Ellis, J.E. and D.M. Swift. 1988. Stability of African pastoral ecosystems: Alternate paradigms and implications for development. J. Range Manage. 41:450-459.

Fernandez, J. R., J. C. Lazaro, and T. H. Flores. 1992. Guia de Germoplasma de Pastos Nativos Andinos, Puno, Peru.

Fjeldsa, J. and M. Kessler. 1996. Conserving the Polylepis Woodlands of the Highland of Peru and Bolivia. A Contribution to Sustainable Natural Resource Management in the Andes. NORDECO, Copenhagen, Denmark.

Harden, C.P. 1993. Land-use, soil erosion, and reservoir sedimentation in an Andean, drainage basin in Ecuador. Mountain Res. and Development 13:177-184.

Heady, H.F. and R.D. Child. 1994. Rangeland Ecology and Management. Westview Press, San Francisco, Calif.

Jongman, R.H.G., C.J.F. ter Braak, and O.F.R. van Tongeren. 1987. Data analysis in community and landscape ecology. Pudoc, Wageningen.

Lavorel, S., J.D. Lebreton, M. Debussche, and J. Lepart. 1991. Nested spatial patterns in seed bank and vegetation of Mediterranean old-fields. J. Veg. Sci. 2:367-376.

LeBaron, A., L.L. Bond, P. Aitken, and L. Michaelsen . 1979. An explanation of the Bolivian highlands grazing-erosion syndrome. J. Range Manage. 32:201-208.

McIntyre, S. and S. Lavorel. 1994. How environmental and disturbance factors influence species composition in temperate Australian grasslands. J. Veg Sci 5:373-384.

Mendiola, M.Q. 1996. Sistema de Pastoreo y Capacidad de Carga Animal en la Comunidad de San Isidro, Departamento de Iruya, Salta. Consejo de Investigación. Universidad Nacional de Salta, Salta, Argentina.
Milchunas, D.G. and W.K. Lauenroth. 1993. Quantitative effects of grazing on vegetation and soils over a global range of environments. Ecol. Monogr. 63:327-366.

Molinillo, M.F. 1993. Is traditional pastoralism the cause of erosive processes in mountain environments? The case of the Cumbres Calchaquies in Argentina. Mountain Res. and Development 13:189-202.

Molinillo, M. and M. Monasterio. 1997 Pastoralism in paramo environments: practices, forage, and impact on vegetation in the Cordillera of Merida, Venezuela. Mountain Res. and Development 17:197-211.

Nadir, A. 1990. Los suelos del N.O.A. (Salta y Jujuy). Prensa de la Universidad Nacional de Salta, Salta.

Noy -Meir, I., M. Gutman, and Y. Kaplan. 1989. Responses of mediterranean grassland plants to grazing and protection. J. of Ecol 77:290-310.

Okland, R.H. and O. Eilertsen. 1994. Canonical Correspondence Analysis with variation partitioning: some comments and an application. J. Veg. Sci. 5:117-126.

Parker, E.G. and H.A. Alzérreca. 1978. Range plant species and range potential on the Bolivian Altiplano. Utah State University, Dept. of Range Science, Logan, Ut.

Reboratti, C. 1996. Sociedad, Desarollo, y Ambiente en la Alta Cuenca del Rio Bermejo. Universidad de Buenos Aires.

Ruthsatz, B. and U. Fisel. 1984. The utilization of natural resources by a small community on the highlands of Bolivia and its effects on vegetation cover and site conditions. Erdwissenschaftliche Forschung XVIII:211-234.

ter Braak, C.J.F. 1987. The analysis of vegetation-environment relationships by canonical correspondence analysis. Vegetatio 69:69-77.

ter Braak, C.J F. 1990a. Update notes: CANOCO version 3.10. Agricultural Mathematics Group, Wageningen, 35 pp. ter Braak, C.J.F. 1990b. Interpreting canonical correlation analysis through biplots of structural correlations and weights. Psychometrika 55:521-531.

ter Braak, C.J.F. and I.C. Prentice. 1988. A theory of gradient analysis. Advances in Ecol. Res. 18:271-317.

Tilman, D. 1990. Constraints and tradeoffs: toward a predictive theory of competition and succession. Oikos 58:3-15.

Turner, M. 1993. Overstocking the range: a critical analysis of the environmental science of Sahelian pastoralism. Econ. Geography 69:402-421.

Viera, O. and M. Menéndez. 1981. Estudio geológico, geomorfológico y de vegetación de los Ríos Nazareno, Iruya e Izcuya en la provincia de Salta. Viera y Menéndez Consultores, 51 pp., Salta, Argentina.

Walkley, A. and I.A. Black. 1934. An examination of the Degtjareff method for determining soil organic matter and a proposed modification of the chromic acid titration method. Soil Sci. 37:29-38.

Warren, S.D., T.L. Thurow, W.H. Blackburn and N.E. Garza. 1986. The influence of livestock trampling under intensive rotation grazing on soil hydrologic characteristics. J. Range Manage. 39:491-495.

West, N.E. 1988. Intermountain deserts, shrub steppes, and woodlands. Pages $210-230$ in M.G. Barbour and W.D. Billings, eds. North American Terrestrial Vegetation. Cambridge University Press, New York.

Westoby, M., B. Walker, and I. Noy-Meir. 1989. Opportunistic management for rangelands not at equilibrium. J. Range Manage. 42:266-274.

Wiens, J.A. 1984. On understanding a nonequilibrium world: Myth and reality in community patterns and processes. In: D.R. Strong, Jr. and A.B. Thistle (eds.), Ecological Communities: Conceptual Issues and the Evidence. Princeton University Press, Princeton, N.J.

Wilcox, B.P., F.C. Bryant, and V.B. Fraga. 1987. An evaluation of range condition on one range site in the Andes of central Peru. J. Range Manage. 40:41-45.

See appendix on page 480 and 481 . 
Appendix. Frequency of occurrence, F(\%), of plant taxa recorded in 57 sites in Nazareno, Depto. Santa Victoria, Salta, Argentina, from January through March, 1997. Species with a frequency less than 7\% were not included in the ordination and are not listed. Associations of taxa with environmental and grazing factors as indicated by RDA are as follows: Aspect: N=North, S=South; Soil type: Cly=Clay-loam, Sdy=Sandy-loam, Phenology: -Phe=early, +Phe=late; Grazing regime: Wet=wet season pasture, Dry=Dry season pasture; Total cover: +Cov=high cover, -Cov=low cover.

$\overline{\overline{\mathrm{F}} \text { Species }}$ class

$(\%)$

86.0 Bidens pseudocosmos /B.exigua Sherff

86.0 Trifolium amabile Kunth

78.9 Dichondra sericea v. . microcalyx $\mathrm{Sw}$

78.9 Plantago tomentosa Lam.

78.9 Stipa ichu (R. et P.) Kunth

71.9 Tagetes pusilla Humb.

66.7 Eragrostis andicola Fries

66.7 Rebulnium richardianum Gillies

64.9 Microchloa indica (Lif.) P. Beauv.

63.2 Oxalis argentina Knuth

57.9 Muhlenbergia rigida (HBK) Trino

52.6 Hypochoeris elata Wedd.

49.1 Bromus catharticus Vahl.

49.1 Stevia minor Gris.

47.4 Elyonurus muticus(Spreng.) Kuntze

45.6 Nasella pampagrandensis (Spreg.)

Barkworth

45.6 Poa sp.

43.9 Ipomoea minuta f.minuta $\mathrm{R}$. Fries

42.1 Cheilanthes pruinata Kaulf.

42.1 Cyperus andinus Palla ex Kuk

42.1 Richardia stellaris Cham.

40.4 Allium spp.

40.4 Hypochoeris meyeniana

v. meyeniana Walp

38.6 Bidens mandonii Sherff

38.6 Festuca spp.

36.8 Arenaria lanuginosa (Michaux)

Rohrb.

36.8 Belloa punae Cabr.

36.8 Pteridophyta spp.

35.1 Galinsoga unixioides Gris.

33.3 Aristida adscensionis v. modesta Hack.

33.3 Deyeuxia tarmensis Pilg.

33.3 Euphorbia prostrata Aiton.

33.3 Stipa pseudoichu Caro

31.6 Vulpia myuros (L.) Gmel. forma megalura (Nutt.) Stace \& Cotton

29.8 Baccharis multiflosculosa Heering
$\mathrm{N},+\mathrm{Cov}$

$+\mathrm{Cov}$

$\mathrm{N}$, Cly, Wet, $+\mathrm{Cov}$

$\mathrm{S}$

Wet, +Cov

N, Sdy

$\mathrm{N}$, Sdy

S

S, Wet

N, Sdy

S, Dry

S, -Phe, Wet,

$+\mathrm{Cov}$

Dry

Sdy

S, Wet, +Cov

S

Dry

Sdy

$\mathrm{S}$

N, Sdy

$\mathrm{S}$

Cly, +Phe, -Cov

$\mathrm{N}$

S

$\mathrm{S},+\mathrm{Phe}$

Sdy, Wet, +Cov

$+\mathrm{Cov}$

N, Sdy

$\mathrm{S}$

$\mathrm{N},-\mathrm{Phe},+\mathrm{Cov}$
$\mathrm{N}$

-Phe, Wet, +Cov

\begin{tabular}{lll}
\hline \hline $\mathrm{F}$ & Species & class \\
\hline$(\%)$
\end{tabular}

29.8 Nasella mucronata (HBK) Pehl

29.8 Stenandrium dulce Car.

28.1 Bowlesia aff. pulchella Wedd.

26.3 Astragalus garbancillo Cav.

26.3 Cynodon hirsutus Stent.

26.3 Gamochaeta subfalcata Cabr.

26.3 Iridaceae $\mathrm{sp}$.

24.6 Adesmia aff. cytisoides "A" Griseb.

24.6 Chondrosum simplex (Lag.) Kunth

24.6 Crassulaceae sp.

24.6 Erodium cicutarium (L.) L'Hér. ex Aiton

24.6 Hypseocharis tridentata Griseb.

24.6 Pennisetum chilense (Desv.) B.D.

Jackdon ex R.E. Fr.

24.6 Satureja parviflora (Phil.) Epling

24.6 Tagetes minuta Linn.

22.8 Parthenium hysteriophorous L.

21.1 Achyrocline ramosissima Sch. Bip.

21.1 Lepechinia meyenii Walp.

21.1 Lycurus phalaroides Kuntze

21.1 Sisyrinchium chilense Hook.

21.1 Viguiera tucumanensis Hook.

21.1 Zinnia peruviana (L.) L.

19.3 Adesmia aff. cytisoides "B" Griseb.

19.3 Chloris halophila Parodi

19.3 Drymaria cordata (L.) Wild. Ex

Roem. et Schult.

19.3 Nierembergia andina Millán

19.3 Stipa sp.

17.5 Amicia medicaginea Griseb.

17.5 Baccharis polifolia Gris.

17.5 Medicago lupulina L.

17.5 Senecio pampae Ling.

17.5 Senna alata (L.) Rox.

15.8 Cerastrium sp.

15.8 Cyperus sp.

15.8 Facelis lasioscarpa Griseb.

15.8 Gutierrezia mandonii Sch. Bip.

15.8 Hypoxis decumbens Linn.

15.8 Balbisia calycina (Griseb.)

A.T. Hunz et Ariza
Wet, +Cov

$\mathrm{N}, \mathrm{Cly}$

$\mathrm{S},+\mathrm{Phe}$

$\mathrm{N},+$ Phe

N, Dry

$+\mathrm{Cov}$

\section{S}

Dry

$\mathrm{N}, \mathrm{Cly}$

Sdy, Wet, +Cov

Sdy

Dry

N, Cly

$\mathrm{N},+\mathrm{Cov}$

$\mathrm{N}$

Sdy

$\mathrm{N}$, Cly

$+\mathrm{Cov}$

-Phe, Wet, +Cov

$\mathrm{S}$

$+\mathrm{Cov}$

Sdy, +Phe

Cly, Dry, -Cov

$+\mathrm{Cov}$ 


\begin{tabular}{|c|c|c|}
\hline$\overline{\mathrm{F}}$ & Spe & class \\
\hline \multicolumn{3}{|l|}{$(\%)$} \\
\hline 14.0 & Agalinis genistifolia Cham. \& Schltdl. & $\mathrm{S}$ \\
\hline 14.0 & Calceolaria fabrisii Botta \& Cabrera & Sdy \\
\hline 14.0 & Eupatorium lorentzii Hier. & $\mathrm{S}, \mathrm{Sdy},+\mathrm{Phe}$ \\
\hline 14.0 & Gomphrena celusioides Mart. & \\
\hline 14.0 & Koeleria sp. & \\
\hline 12.3 & Apium sp. & \\
\hline 12.3 & Dichondra argentea $\mathrm{H}$. et. B. & Cly, -Cov \\
\hline 12.3 & Gentianella benedictae (Gilg.) Fabris & $\mathrm{S}$ \\
\hline 12.3 & Solanum spegazzinii Bitter & \\
\hline 12.3 & Sporobolus indicus (L.) R. Br. & Wet, +Cov \\
\hline 10.5 & Aphanostelma parviflorum Malme & \\
\hline 10.5 & Botriochloa sp. & Dry \\
\hline 10.5 & Commelina aff. virginica $\mathrm{L}$. & $-\mathrm{Phe},+\mathrm{Cov}$ \\
\hline 10.5 & Evolvulus sericeus Sw. v. sericeus & $\mathrm{N}$ \\
\hline 10.5 & Geranium sessiliflorum Car. & \\
\hline 10.5 & Hieracium neofurcatum Sleum. & \\
\hline 10.5 & Malaxis padilliana L.O. Williams & \\
\hline 10.5 & Mutisia acuminata v. paucijuga Gris. & -Phe \\
\hline 10.5 & Opuntia soehrendsii Britton \& Rose & \\
\hline 10.5 & Oxalis bisfracta Tucrz. & S \\
\hline 8.8 & Anemone decapetala Ard. & \\
\hline 8.8 & Bulbostylis sp. & \\
\hline 8.8 & Hieracium dasychaetocomum Zahn & \\
\hline 8.8 & Hoffmanseggia yaviensis & \\
\hline 8.8 & Mitracarpus brevis Schum. & $\mathrm{S}$ \\
\hline 8.8 & Paspalum humboldtianum Flugge & Dry \\
\hline 8.8 & Peperomia peruviana (Dhlst.) Miq. & \\
\hline 8.8 & Polygala mendocino Phil. & \\
\hline 8.8 & Stevia lilloi Rob. & \\
\hline 8.8 & Trichocline auriculata v. auriculata Wedd. & \\
\hline 7.0 & Astragalus sp. & \\
\hline 7.0 & Calycera pulvinata Remy. & \\
\hline 7.0 & Conyza serrana Cabr. & S \\
\hline 7.0 & Conyza spiciformis Griseb. & $\mathrm{S},+\mathrm{Phe}$ \\
\hline 7.0 & Diplachne dubia (HBK) Scribn. & Dry \\
\hline 7.0 & Eupatorium prassiflolium Gris. & \\
\hline 7.0 & Gnaphalium jujuyense Cabrera & \\
\hline 7.0 & Luzula peruviana Gmeln. & \\
\hline 7.0 & Muhlenbergia peruviana (P. Beauv.) Steud. & Sdy, +Phe \\
\hline 7.0 & Orchidaceae sp. & \\
\hline 7.0 & Primulaceae sp. & \\
\hline 7.0 & Stellaria antoniana Volponi & -Phe \\
\hline
\end{tabular}

